\title{
Tinjauan Hukum Humaniter Internasional dalam Operasi Enduring Freedom Amerika Serikat ke Afghanistan dan Peran International Criminal Court (ICC)
}

\author{
Reno Ismadi, Awatar Bayu Putranto, Tiffany Setyo Pratiwi \\ Program Studi Hubungan Internasional, Universitas Teknologi Yogyakarta - Indonesia \\ Email: enhorio11@gmail.com \\ Diserahkan: 2 April 2019 | Diterima: 24 April 2019
}

\begin{abstract}
The US military invasion to Afghanistan took place when the War on Terror declared by the United States after the incident in September, 2001 at World Trade Center. One of the military operations in this invasion was called Enduring Freedom. This research will discuss the violations committed by America in the invasion of Afghanistan, particularly during the Enduring Freedom operation, which it was reviewed through Geneva Law and The Rome Statute. The author using literature studies with qualitative methods. The author found that the violations of the Geneva Conventions of 1949 and The Rome Statute Article 8 and 11 were carried out by America during the deliberate Enduring Freedom Operation. The violation was proven but the International Criminal Court (ICC) did nothing.
\end{abstract}

Keywords: United States of America, Afghanistan, Geneva Law, Rome Statute, War, Crimes.

\begin{abstract}
Abstrak
Invasi militer Amerika Serikat ke Afghanistan terjadi pasca War on Terror yang di deklarasikan Amerika Serikat setelah kejadian di World Trade Center September Tahun 2001. Salah satu operasi militer dalam invasi ini disebut Enduring Freedom. Tulisan ini akan membahas mengenai pelanggaran yang dilakukan oleh Amerika Serikat pada invasi Afghanistan pada saat operasi Enduring Freedom yang ditinjau melalui Hukum Jenewa dan Statuta Roma. Penulis menggunakan studi kepustakaan dengan metode kualitatif. Penulis menemukan bahwa pelanggaran terhadap Konvensi Jenewa 1949 dan Statuta Roma Pasal 8 dan 11 dilakukan oleh Amerika Serikat selama Operasi Enduring Freedom secara sengaja dilakukan. Pelanggaran tersebut sudah terbukti namun Pengadilan Kejahatan Internasional tidak berbuat apa-apa.
\end{abstract}

Kata Kunci: Amerika Serikat, Afganistan, Hukum Jenewa, Statuta Roma, Kejahatan, Perang.

\section{PENDAHULUAN}

Perhatian warga Amerika Serikat masih tertuju pada serangan yang terjadi di World Trade Center (WTC), pesawat American Airlines jenis Boeing 757 berputar mengelilingi Washington DC sebelum akhirnya menabrakkan diri ke sisi barat markas Pentagon pada pukul 09:45 waktu Amerika Serikat.
Serangan ketiga ini terjadi satu jam setelah serangan pertama yang kemudian menyebabkan 125 personil militer Amerika Serikat tewas. Kemudian 15 menit setelah serangan ke Pentagon, gedung WTC yang sebelumnya ditabrak menjadi runtuh. Sedangkan pesawat keempat yang 
sebelumnya dibajak yaitu United Airlines menabrakkan diri, menyebabkan 44 orang dinyatakan tewas. Atas peristiwa tersebut, total ada 2.996 orang terbunuh. WTC menjadi lokasi dengan jumlah korban terbanyak sebesar 2.763 orang yang diantaranya 343 pemadam kebaran dan paramedis, 23 polisi, dan 37 petugas evakuasi. Korban di Pentagon mencapai angka 189 orang termasuk 64 penumpang pesawat (Widyaningrum, 2018). Inilah awal penyebab kisah tragis di tanah Afghanistan bermula.

Pada 7 Oktober 2001, sebulan setelah serangan, Presiden Bush resmi menjadikan Afghanistan sebagai medan tempur antara Amerika Serikat dengan kelompok ekstrimis Taliban dan Al-Qaeda. Amerika Serikat dan negara barat berupaya menjadikan terorisme sebagai bentuk ancaman baru terhadap demokrasi. "Either you are with us or you are with the terrorism" merupakan penggalan pidato George Bush yang membuat negara-negara di dunia menjadi dilematik karena harus menentukan posisi mereka. Pihak yang sejalan dengan Amerika Serikat akan disebut sebagai teman dan yang menolak akan disebut sebagai musuh. Jika menolak, maka siap dicap sebagai anti demokrasi dan poros kejahatan (the axis of evil). Hal ini menunjukkan betapa kuatnya hegemoni Amerika Serikat di dunia hingga dapat mengakomodir banyak negara untuk mengganggap terorisme sebagai musuh bersama. Namun dampak dari hegemoni Amerika Serikat terhadap isu terorisme memunculkan bias definisi terorisme. Untuk dapat disebut sebagai teroris dan bukan teroris harus sesuai dengan kriteria yang dibuat Amerika Serikat (Bhaskara, 2018).

Dalam pidatonya juga, Bush (2002) merincikan tentang tiga tugas untuk melindungi Amerika Serikat dengan menyatakan:

"We wil defend the peace by fighting terrorist and tyrants. We wil preserve the peace by building good relations among the great powers. We will extend the peace by encouraging free and open societies on every continent" (Bush, 2002).

Kalimat yang diucapkan oleh George Bush tersebut bertentangan dengan apa yang sebelumnya dicita-citakan oleh Bill Clinton pada 1998 yang mendorong peningkatan ekonomi melalui promosi demokrasi dan hak asasi manusia di luar negeri. Pernyataan Bush menggambarkan cara apa yang akan digunakan nantinya untuk mencapai tujuan tersebut, dan bisa dilihat bahwa ucapannya berakhir dengan invasi Amerika Serikat Serikat ke Afghanistan yang biasa dikenal sebagai $W$ ar on Terror dan operasi Enduring Freedom (Kattelman, 2014, p. 12). 
Rencana utama dari operasi ini adalah menggunakan persenjataan udara dengan presisi tinggi ditambah lagi dibantu dengan bantuan pasukan darat khusus Amerika Serikat yaitu Special Operation Forces (SOF). Serangan pertama dari operasi ini dimulai pada 7 Oktober 2001 di mana Amerika Serikat memulai serangan pada malam hari. Dari serangan ini beberapa markas dan faasilitas Taliban berhasil dilumpuhkan (Lambeth, 2005). Namun semakin jauh operasi tersebut berjalan, banyak pelanggaran perang yang melibatkan tentara Amerika Serikat, mulai dari serangan, pembunuhan, dan pengeboman terhadap kelompok sipil.

Sejumlah pelanggaran ini menjadi penting untuk diteliti berdasarkan perspektif hukum humaniter internasional. Tulisan ini fokus pada 2 hal penting. Pertama, penerapan Hukum Jenewa dan Statuta Roma terkait kasus kejahatan perang pada operasi Enduring Freedom tahun 20012003. Kedua, menganalisis peran lembaga pengadilan internasional (ICC) untuk membawa Amerika Serikat ke meja persidangan. Selain itu, tulisan ini juga akan membandingkan bentuk kejahatan perang yang terjadi dalam peristiwa Nanking.

\section{KERANGKA ANALISIS}

\section{Geneva Convention of 1949 for the Protection of Victims of War}

Konvensi atau Hukum Jenewa mengalami beberapa kali perubahan yaitu pada 1906, 1929, 1949, dan protokol tambahan 1977. Tulisan ini akan fokus pada konvensi Jenewa 1949 yang terdiri dari empat poin. Pertama, Konvensi Jenewa untuk perbaikan keadaan bagi yang Luka dan Sakit dalam Angkatan Bersenjata di Medan Pertempuran Darat (Geneva Convention for the Amelioration of the Condition of the Wounded and Sick in Armed Forces in the Field). Kedua, Konvensi Jenewa untuk Perbaikan Keadaan Anggota Angkatan Bersenjata yang Luka, Sakit dan Korban Karam di Laut (Geneva Convention for the Amelioration of the Condition of the Wounded, Sick and Shipwrecked Members or Armed Forces at Sea). Ketiga, Konvensi Jenewa mengenai Perlakuan Tawanan Perang (Geneva Convention relative to the Treatment of Prisoners of War). Keempat, Konvensi Jenewa mengenai Perlindungan Orang Sipil di waktu Perang (Geneva Convention relative to the Protection of Civilian Persons in the Time of $W$ ar).

Konvensi 1949 tersebut kemudian dikenal dengan nama Hukum Jenewa (Kusumaatmadja, 2011). Hukum Jenewa dan juga Hukum Den Haag disebut sebagai Hukum Humaniter yang istilah lamanya adalah Hukum Perang. 
Hukum Humaniter bersifat mengikat bagi negara yang telah meratifikasi termasuk di dalamnya individuindividu angkatan bersenjata, kepala negara, menteri dan pejabat-pejabat lainnya (Deliana, 2011, p. 259).

\section{Statuta Roma}

Kejahatan perang menurut Hukum Jenewa dijelaskan pada pasal 8 ayat 2 (a): Pelanggaran berat terhadap Konvensi Jenewa tertanggal 12 Agustus 1949, yaitu masing-masing dari perbuatan berikut ini terhadap orang-orang atau hak milik yang dilindungi berdasarkan ketentuan Konvensi Jenewa yang diantaranya (Nasution, 2006, 674); (i) pembunuhan yang dilakukan dengan sadar; (ii) penyiksaan atau perlakuan tidak manusiawi, termasuk percobaan biologis; (iii) secara sadar menyebabkan penderitaan berat, atau luka serius terhadap badan atau kesehatan; (iv) perusakan meluas dan perampasan hak milik, yang tidak dibenarkan oleh kebutuhan militer dan dilakukan secara tidak sah dan tanpa alasan; (v) memaksa seorang tawanan perang atau orang lain yang dilindungi untuk berdinas dalam pasukan dari suatu Angkatan Perang lawan; (vi) secara sadar merampas hak-hak seorang tawanan perang atau orang lain yang dilindungi atas pengadilan yang jujur dan adil; (vii) deportasi tidak sah atau pemindahan atau penahanan tidak sah; (viii) menahan sandera.

Pasal 8 ayat (b) pelanggaran serius lain terhadap hukum dan kebiasaan yang dapat diterapkan dalam sengketa bersenjata internasional, dalam rangka hukum internasional yang ditetapkan, yaitu salah satu perbuatan-perbuatan berikut: (i) Secara sengaja melancarkan serangan terhadap sekelompok penduduk sipil atau terhadap setiap orang sipil yang tidak ikut serta secara langsung dalam pertikaian itu; (ii) Secara sengaja melakukan serangan terhadap objekobjek sipil, yaitu objek yang bukan merupakan sasaran militer; (iii) Secara sengaja melakukan serangan terhadap personil, instalasi, material, satuan atau kendaraan yang terlibat dalam suatu bantuan kemanusiaan atau misi penjaga perdamaian sesuai dengan Piagam Perserikatan Bangsa-Bangsa, sejauh bahwa mereka berhak atas perlindungan yang diberikan kepada objek-objek sipil berdasarkan hukum internasional mengenai sengketa bersenjata; (iv) Secara sengaja melancarkan suatu serangan dengan mengetahui bahwa serangan tersebut akan menyebabkan kerugian insidential terhadap kehidupan atau kerugian terhadap orang-orang sipil atau kerusakan terhadap objek-objek sipil atau kerusakan yang meluas, berjangka panjang dan berat terhadap lingkungan alam yang jelas-jelas terlalu 
besar dalam kaitan dengan keunggulan militer keseluruhan secara konkrit dan langsung dan yang dapat diantisipasi; (v) Menyerang atau membom, dengan sarana apapun, kota-kota, desa, perumahan atau gedung yang tidak dapat dipertahankan atau bukan objek militer.

$\begin{array}{cll}\text { Pasal } & 11 \quad \text { Yuridiksi } & \text { Ratione } \\ \text { Temporis } & \text { menyatakan } & \text { bahwa }\end{array}$

Pengadilan mempunyai yuridiksi hanya berkaitan dengan kejahatan yang dilakukan setelah berlakunya Statuta ini. Kalau suatu negara menjadi pihak dari statuta ini setelah statuta ini mulai berlaku, Pengadilan dapat melaksanakan yuridiksinya hanya berkenaan dengan kejahatan yang dilakukan setelah diberlakukannya statuta ini untuk negara tersebut, kecuali kalau negara tersebut telah membuat suatu deklarasi berdasarkan pasal 12 ayat 3, negara tersebut dapat, dengan deklarasi yang disampaikan kepada Panitera, menerima pelaksanaan yuridiksi oleh pengadilan berkenaan dengan kejahatan yang dipersoalkan. Negara yang menerima kerjasama dengan pengadilan tanpa ditunda-tunda lagi atau pengecualian.

\section{HASIL DAN PEMBAHASAN}

\section{Pelanggaran HAM dalam Operasi Enduring Freedom}

Berdasarkan data yang dirilis Human Rights Watch ditemukan beberapa bukti bahwa operasi militer
Enduring Freedom telah melanggar hak asasi manusia. Beberapa pelanggaran tersebut dapat dicontohkan dengan adanya penangkapan yang tanpa pandang bulu dengan kekuatan masif, adanya korban salah tangkap, dan penahanan dengan waktu yang lama tanpa proses pengadilan, adanya penganiayaan terhadap tahanan dan tindakan-tindakan lain yang telah menimbulkan luka fisik hingga korban nyawa (HRW, 2004).

\section{Kasus Penangkapan Ahmed Khan}

Salah satu bentuk pelanggaran yang terjadi dalam operasi militer ini adalah terjadinya penangkapan dengan menggunakan kekuatan yang berlebihan. Salah satu kasus nyata dari tindakan ini adalah peristiwa yang terjadi pada Ahmed Khan dan keluarganya pada akhir Juli 2002. Pada malam yang naas tersebut pasukan dari Amerika Serikat melakukan penggeledahan terhadap rumah dari Ahmed Khan yang terletak pada distrik Zurmat provinsi Paktia, Ahmed Khan dan kedua anaknya yang berumur 17 dan 18 tahun ditangkap oleh pasukan Amerika Serikat dan koalisinya. Aksi penangkapan ini juga memakan korban jiwa dan satu korban terluka, satu orang petani meninggal karena luka tembak dari prajurit Amerika Serikat dan satu orang wanita yang bertempat tinggal dekat dengan 
rumah dari Ahmed Khan juga terluka (HRW, 2004).

Human Rights Watch yang melakukan wawancara terhadap warga sekitar yang menyaksikan aksi dari pasukan Amerika Serikat dan menyatakan bahwa pada penangkapan Ahmed Khan ini. Pasukan Amerika Serikat menggunakan senjata peledak dan bahkan menggunakan kendaraan seperti helikopter yang sempat menembakan senapan mesin. Pada saat serangan itu terjadi, Ahmed dan keluarganya bersembunyi di bawah tempat tidur di kamar lantai kedua di rumahnya. Ketika serangan dengan helikopter telah selesai, pasukan dari Amerika Serikat memasuki rumah dari Ahmed dengan menembak pintu dari rumah tersebut, beberapa prajurit memasuki rumah tersebut melalui jendela yang telah pecah karena serangan dari helikopter, setelah itu Ahmed dan keluarganya ditodong dengan senapan mesin dan diminta untuk mengangkat tangan mereka ke udara dan berjalan ke halaman rumah mereka.

Setelah kasus ini mereda, Ahmed Khan dan kedua anaknya dipulangkan, Ahmed menyatakan pada Human Rights Watch bahwa pada saat serangan tersebut terjadi ada beberapa barang pribadi dan harta kekayaan dari Ahmed yang hilang, barang-barang tersebut disebut oleh Ahmed seperti perhiasan dan harta berharga lainnya.
Penangkapan keluarga Ahmed adalah salah satu kasus yang terungkap dari data Human Rights Watch.

\section{Penahanan dan Prosekusi serta Kesalahan Penangkapan}

Saksi bisu lain pelanggaran HAM adalah Bagram, sebuah kota di utara Kabul, Afghanistan, tempat rahasia sebagai penjara mereka yang ditangkap oleh pasukan militer Amerika Serikat. Diketahui bahwa beberapa mantan tahanan dari Bagram menyatakan bahwa selain adanya kekerasan fisik dan perlakuan tidak manusiawi dari penjaga dan pasukan di sana, tahanan juga merasakan adanya trauma psikologis yang disebabkan karena lamanya waktu mereka menjadi tahanan dan terkadang adanya prosekusi yang tidak adil, kedua hal di atas menjadi alasan dari beberapa tahanan merasa kehilangan harapan dan putus asa.

Salah satu bentuk perlakuan di atas dapat kita teliti lebih jauh melalui banyaknya kasus yang didapat dari DFIP atau detention facility in Paswan. Salah satu kasusnya di mana Ayaz pemuda berumur 15 tahun yang pergi ke Afghanistan untuk mencari perkerjaan di sana, Ayaz berasal dari Pakistan. Pada satu hari ketika Ayaz sedang bekerja di sebuah restoran, pasukan Amerika Serikat datang dan menanyakan informasi tentang Ayaz, tidak berselang lama Ayaz dibawa ke 
salah satu markas militer di Provinsi Paktia, Ayaz memiliki kecurigaan bahwa rekan kerjanya telah memberikan informasi palsu kepada pasukan Amerika Serikat sebagai ganti uang. Setelah enam tahun mengahabiskan waktu sebagai tahanan di sana Ayaz berhasil kembali ke Pakistan pada tahun 2011 melalui program repatriasi (Belhadi, 2009).

Selain Ayaz ada pula Malik seorang pedagang Irak juga mengkritik keras sistem yang berlaku di sana. Malik merupakan exportir beras dari Irak yang pada suatu hari ditangkap oleh pasukan Inggris dan diserahkan kepada pasukan Amerika Serikat. Pada masa tahanan Malik di Paswan hampir sama seperti tahanan yang lain Mailk menjadi korban kekerasan fisik. Pada saat persidangan Malik memberikan pernyataan dengan keadaan yang cukup parah dengan mata yang membengkak, tulang rusuk yang patah, dan mulut yang terluka. Malik juga merasa putus asa karena sebagai seorang tahanan ia ditangkap tanpa ada alasan yang jelas. Malik juga pernah meminta pada biro yang akan mewakili sidangnya untuk memberikan bukti asosiasinya dengan teroris (Belhadi, 2009).

Selain kedua pria di atas, Jibran seorang remaja dari Pakistan yang baru berumur 16 tahun juga dipenjarakan di Paswan hingga lima tahun, Jibran ditahan pada tahun 2004. Jibran ditangkap oleh Pasukan Amerika Serikat ketika sedang menemani temannya yang memiliki kelainan mental, untuk mencari tabib. Setelah itu Jibran dijebloskan selama 40 hari ke dalam penjara di Kandahar, kemudian ia ditransfer ke tempat penahanan lainnya. Masa penahanan Jibran selama 5 tahun tersebut secara perlahan membuat remaja itu mulai kehilangan harapan untuk kembali ke Pakistan. Pada tahun 2009, Jibran dilepaskan dari Paswan, karena otoritas yang terkait tidak dapat mencari bukti yang mencukupi, salah satu dari Pasukan Amerika Serikat meminta maaf atas penangkapan dan penahanannya, namun Jibran masih merasa marah karena lima tahun dari kehidupannya telah hilang sebagai tahanan (Belhadi, 2009). Ayaz, Malik, dan Jibran adalah tiga orang yang disiksa tanpa proses pengadilan, bahkan mereka tidak bersalah oleh Amerika Serikat dalam operasi Enduring Freedom.

\section{Penegakan Hukum Jenewa dan Statuta Roma dalam Operasi Enduring Freedom}

Pada kasus serangan terhadap keluarga Ahmed Khan, pasukan Amerika Serikat telah melanggar Hukum Jenewa 1949 pada poin mengenai perlindungan orang sipil di waktu perang dan melanggar Statuta Roma pasal 8 ayat 2 (a) nomor 4 mengenai perusakan meluas dan 
perampasan hak milik, yang tidak dibenarkan oleh kebutuhan militer dan dilakukan secara tidak sah dan tanpa alasan serta pasal 8 ayat (b) nomor 1 dan 2 tentang larangan untuk menyerang penduduk sipil dan objek sipil. Sedangkan pada kasus kekerasan terhadap anak-anak di provinsi Uruzgon, pasukan Amerika Serikat telah melanggar Hukum Jenewa 1949 pada poin mengenai perlindungan orang sipil di waktu perang dan melanggar pasal 8 ayat (b) Statuta Roma nomor 1 tentang larangan menyerang penduduk sipil.

Untuk kasus ketiga yaitu pembunuhan pasangan dan enam orang anak di Koswen, Amerika Serikat telah melanggar Jenewa 1949 pada poin mengenai perlindungan orang sipil di waktu perang dan melanggar Statuta Roma pasal 8 ayat 2 (a) nomor 1 mengenai pembunuhan yang dilakukan dengan sadar dan pasal 8 ayat (b) nomor 1 dan 2 tentang larangan untuk menyerang penduduk sipil dan objek sipil serta nomor 4 secara sengaja melancarkan suatu serangan dengan mengetahui bahwa serangan tersebut akan menyebabkan kerugian insidential terhadap kehidupan atau kerugian terhadap orang-orang sipil atau kerusakan terhadap objek-objek sipil atau kerusakan yang meluas, berjangka panjang dan berat terhadap lingkungan alam yang jelas-jelas terlalu besar dalam kaitan dengan keunggulan militer keseluruhan secara konkrit dan langsung dan yang dapat diantisipasi. Nomor 5 tentang menyerang atau membom, dengan sarana apapun, kota-kota, desa, perumahan atau gedung yang tidak dapat dipertahankan atau bukan objek militer. Selain itu Amerika Serikat juga memperlakukan tahanan dengan sangat tidak manusiawi, seperti memberikan makanan yang tidak layak, kondisi penjara yang tidak memadai sehingga waktu istirahat bagi tahanan menjadi sangat minim dan adanya larangan untuk para tahanan yang notabenenya merupakan pemeluk agama Islam untuk menjalankan ibadah.

Tindakan-tindakan seperti ini telah jelas melanggar Konvensi III Jenewa, terlebih banyaknya bukti dan kesaksian dari mantan tahanan juga memperkuat pandangan bahwa Amerika Serikat Serikat tidak secara sepenuhnya menegakan isi dari konvensi Jenewa dalam operasi militer mereka.

Berdasarkan pasal 11 Yuridiksi Ratione Temporis, ketiga kasus di atas seharusnya dapat diselesaikan melalui International Criminal Court (ICC) karena peristiwa tersebut terjadi setelah Statuta Roma resmi berlaku pada 1 Juli 2002. Namun kekuatan yuridiksi ICC patut dipersoalkan ketika yang dihadapi adalah negara yang tidak 
meratifikasi Statuta Roma seperti Amerika Serikat.

\section{Ketidakberdayaan ICC pada Kasus Kejahatan Perang Operasi Enduring Freedom}

ICC adalah institusi yudisial yang dibentuk dalam rangka menyelesaikan pelanggaran HAM. ICC merupakan lembaga yang bersifat permanen yang didirkan berdasarkan Statuta Roma tahun 1998. Mulai berlaku pada 1 Juli 2002 dan diratifikasi oleh 60 negara. ICC hanya memiliki wewenang atas kejahatan-kejahatan serius yang menjadi keprihatinan masyarakat internasional seperti genosida, kejahatan terhadap kemanusiaan, kejahatan perang, dan kejahatan agresi. Yuridiksi ICC hanya bisa diterapkan kepada negara yang meratifikasi Statuta Roma atau kewarganegaraan pelaku merupakan warga negara peserta Statuta Roma (Sujatmoko, 2015, p. 50).

Pada awalnya, Amerika Serikat merupakan negara yang turut serta meratifikasi Statuta Roma, tepatnya pada era Bill Clinton tahun 1998. Keputusan Clinton tersebut cukup banyak ditentang oleh senat dan bahkan beberapa senator dari partainya sendiri. Namun Amerika Serikat kemudian menarik diri dari Statuta Roma pada saat George Bush memimpin (Casey, 2001, pp. 840-841). Amerika Serikat dalam kasus ini memang bukan merupakan negara yang meratifikasi Statuta Roma. Namun dalam kasus invasi ke Afghanistan, Amerika Serikat tetap dapat dibawa ke meja pengadilan. Seorang Jaksa bernama Fatou Bensouda telah meminta kekuasaan kepada tiga hakim untuk menginvestigasi kejahatan yang dilakukan oleh semua pihak yang terlibat perang seperti Taliban, ISIS, tentara Afghanistan dan tentara Amerika Serikat.

Meskipun Amerika Serikat bukan merupakan negara yang meratifikasi Statuta Roma, ICC menganggap memiliki kekuasaan untuk menjerat Amerika Serikat karena terjadinya kejahatan perang tersebut berada di wilayah Afghanistan yang notabene merupakan negara peserta Statuta Roma (Davert, 2018). Akan tetapi, langkah ICC untuk dapat membawa Amerika Serikat ke persidangan akan sangat sulit. Pasalnya Amerika Serikat mengancam memberhentikan bantuan kepada negara yang mendukung ICC untuk menyeret warga Amerika Serikat ke pengadilan. Kemudian Amerika Serikat membuat perjanjian dengan beberapa negara berdasarkan pasal 98 Statuta Roma yang berisi:

"Cooperation with waiver of immunity and consent to surrender: (1) the court may not proceed with a request for surrender or assistance which would require the requested state to act 
inconsistenly with its obligation under international law with respect to the state or diplomatic immunity of a person or property of a third state, unless the court can first obtain the cooperation of that third state for the waiver of the immunity; (2) the court may not proceed with a request for surrender which would require the requested state to act inconsistenly with its obligations under international agreement pursuant to which the consent of a sending state is required to surrender a person of that state to the court, unless the court can obtain the cooperatioan of the sending state for giving of consent for the surrender".

Pasal dari Statuta Roma tersebut memilki celah yang dapat meloloskan negara-negara dari ICC (Effendi, 2007, 24-25). Kembali lagi bahwa hegemoni Amerika Serikat membuat Hukum Humaniter tidak berdaya. Amerika Serikat menjadi aktor antagonis dengan menolak untuk bekerjasama dengan pengadilan ICC. Amerika Serikat secara aktif menghambat atau menekan negara lain untuk melakukan hal yang sama. Wakil Menteri bidang Kontrol Senjata dan Keamanan Nasional menyebut bahwa ada tiga hal yang akan membuat ICC tidak berdaya sebelum Office of the Prosecutor (Kantor Kejaksaan) benar-benar stabil. Bolton menyebutnya dengan "the three noes", yang berarti "no financial support, directly or indirectly, no collaboration, and no further negotiations with other governments to improve the statue (Chang, 2009). Dengan adanya pernyataan tersebut menunjukkan betapa seriusnya ancaman Amerika Serikat terkait ICC.

\section{Perbandingan Kejahatan Perang Pada Kasus Pembantaian dan Pemerkosaan Nanking}

Sebelum invasi Amerika Serikat ke Irak, dunia sudah diperlihatkan pada konflik militer dengan skala yang lebih besar seperti Perang Dunia I dan Perang Dunia II. Jepang selalu diingat sebagai negara yang menjajah dengan kekejaman yang luar biasa seperti penjajahan yang terjadi di Nanking, Cina. Penjajahan yang disertai pembunuhan dan pemerkosaan di Nanking meninggalkan luka mendalam bagi rakyat Nanking. Ketika negara pemenang perang seperti Amerika Serikat dan sekutunya mengorganisir persidangan bagi para penjahat perang, di situlah sebuah asa rakyat Nanking untuk menuntut keadilan mulai terlihat (Chang, 2009).

Upaya untuk menyeret penjahat perang ke meja pengadilan sudah dimulai bahkan sebelum Perang Dunia II berakhir. Amerika Serikat dan pemerintahan nasionalis Cina membuat skenario dahulu untuk pengadilan-pengadilan tersebut. Pada Maret 1944, PBB menciptakan badan investigasi untuk menyelidiki kejahatan-kejahatan perang, sebuah sub-komite untuk kejahatan-kejahatan 
perang Timur Jauh dan Pasifik yang didirikan di Chungking, ibukota Cina selama masa perang. Setelah Jepang menyerah, rencana pengadilan mulai dilakukan dengan serius. Para penguasa Jepang yang terlibat kejahatan seperti pemerkosaan diadili di Nanking dan juga Tokyo (Chang, 2009).

Pengadilan yang dilakukan di Jepang dikenal dengan nama International Military Tribunal for Far East (IMFTE). Persidangan dimulai pada 3 Mei 1946 dengan membawa 200.000 penonton dan 419 saksi mata. Transkrip persidangan menghabiskan 49.000 halaman, berisi 10.000 .000 kata, 779 afidavit, dan 4.336 bukti. Persidangan IMFTE berlangsung selama 2,5 tahun dan dianggap akan menjadi persidangan terpanjang dalam sejarah (Chang, 2009, p. 209).

Beberapa tokoh yang diseret pada persidangan salah satunya adalah Tani Hisao. Tani Hasao adalah seorang Letnan Jenderal Divisi ke-6 yang bertugas pada tahun 1937 di Nanking. Divisi yang dibawahi oleh Tani Hisao dianggap banyak melakukan kekejaman di Nanking. Pada 1946 Tani Hisao dibawa kembali ke Cina untuk menjalani persidangan. Tani Hisao didakwa dengan bukti 5 kuburan massal yang berisi ribuan kerangka manusia di dekat pintu gerbang Chunghua. Tani Hisao dituduh atas kasus pembunuhan yang berjumlah ribuan, pembakaran, penenggelaman, pencekikan, pemerkosaan, pencurian, dan penghancuran yang dilakukan Divisi Hisao. Tani Hisao kemudian dituntut bersalah pada 10 Maret 1947 yang kemudian dijatuhi hukuman mati karena dinilai melanggar Konvensi Den Haag tentang kebiasaan perang darat dan perlakuan tahanan perang selama perang berlangsung (Chang, 2009, pp. 207-208).

Selain Tani Hisao, tokoh yang kemudian diadili lainnya adalah Matsui Iwane, Komandan Pasukan Ekspedisi Cina Pusat Jepang. Sebelum invasi ke Nanking dilakukan, Matsui menyebut bahwa misinya adalah untuk menghukum pemerintah dan masyarakat Nanking. Matsui dinyatakan bersalah atas seluruh kejahatan yang terjadi di Nanking. Pengadilan kemudian menjatuhkan hukuman mati kepada Matsui beserta 7 orang lainnya termasuk Menteri Luar Negeri Jepang, Hirota Koki yang kemudian digantung di penjara Sugamo Jepang (Chang, 2009, pp. 211213).

\section{Standar Ganda Amerika Serikat dan Penegakan Keadilan atas Kejahatan Perang}

Ketika melihat lebih jauh tentang penegakan keadilan terhadap korbankorban kejahatan perang, maka salah satu kasus yang relevan adalah International Military Tribunal for Far 
East (IMFTE) di Tokyo. Pada masa itu, Amerika Serikat merupakan pihak yang berkontribusi besar untuk membawa para pejabat Jepang ke meja pengadilan hingga repot-repot merancang pengadilan ad boc (Martowirono, 2001). IMFTE memang merupakan pengadilan yang dibuat khusus untuk mengadili tokohtokoh Jepang dan bukan merupakan lembaga permanen seperti ICC. Nama-nama pejabat yang terlibat dipublikasikan dan proses persidangan dihadiri ratusan ribu penonton dan saksi. Hal ini menunjukkan pemberlakuan hukum yang adil bagi korban. Singkatnya, Amerika Serikat menunjukkan citra yang baik sebagai negara pemenang perang dan melakukan standar ganda dengan memaksa negara lain untuk menjalani proses hukum namun menolak apabila hukum tersebut menjerat Amerika Serikat.

Berdasarkan kasus penegakan hukum terhadap Amerika Serikat pada operasi Enduring Freedom, dapat dilihat bahwa lembaga yudisial permanen seperti ICC sekalipun kesulitan menjerat Amerika Serikat. Hal ini menunjukkan bahwa lembaga pengadilan ad hoc pada sejarahnya lebih memiliki peran yang efektif dan maksimal karena adanya kontribusi negara pemenang perang dibanding lembaga permanen seperti ICC. Masalah utama penegakan hukum humaniter bukan pada seberapa kuat legitimasi hukumnya, namun lebih kepada seberapa kuat aktor yang mendukung penegakan hukum.

\section{KESIMPULAN}

Pada dasarnya, dalam operasi militer Enduring Freedom terdapat banyak sekali bentuk-bentuk pelanggaran hak asasi manusia baik terhadap tahanan perang maupun terhadap warga sipil. Hampir tidak ada pembedaan antara warga sipil dan kombatan dari pasukan teroris. Salah satu bentuk pelanggaran yang terjadi, di antaranya: penggunaan kekerasan yang berlebihan dalam penangkapan, penyiksaan tahanan, masa tahanan yang sangat lama dan penyiksaan, yang melanggar Hukum Jenewa poin ke III tentang perlakuan terhadap tahanan dan poin ke IV tentang perlindungan terhadap warga sipil. Bahkan senjata yang digunakan dalam operasi militer ini terlalu berlebihan.

Implementasi Hukum Jenewa dan Statuta Roma jelas tidak terjadi pada kasus Enduring Freedom, apalagi terkendala dengan tidak kooperatifnya Amerika Serikat untuk menjunjung penegakan hukum perang. Jika melihat pada asas proportion dalam kaitannya dengan Jus in Bellum, tindakan Amerika Serikat yang menginvasi Afghanistan atas dasar war on terror tampak irasional. Irasionalitas ini dapat ditunjukkan dalam tindakan 
Amerika Serikat yang menggunakan banyak sekali serangan udara untuk menghancurkan infastruktur dan markas Taliban dan Al-Qaeda. Serangan tersebut sebagian meleset, bahkan Osama Bin Laden juga sempat kabur dengan gempuran serangan udara yang dilakukan oleh militer Amerika Serikat. Konsekuensinya adalah munculnya korban dipihak sipil. Selain itu, serangan balasan terhadap kelompok terorisme dengan menginvasi sebuah negara juga tidak masuk akal, terlebih Amerika Serikat mengikutsertakan pasukan koalisi dalam invasi ini.

Kekuatan dan posisi untuk mempengaruhi negara lain menjadikan Amerika Serikat dapat memproteksi diri dari segala jeratan dan tuntutan hukum. Pasal tentang perlindungan sipil di dalam Hukum Jenewa dan Statuta Roma seperti tidak memiliki kekuatan lagi untuk dapat melindungi korban perang. Amerika Serikat tidak secara sepenuhnya menegakan isi dari konvensi Jenewa dalam operasi militer mereka dan telah gagal melindungi dan menciptakan rasa aman bagi warga sipil di Afghanistan pada operasi militer Enduring Freedom. Bahkan ICC yang lahir dari Statuta Roma dan difungsikan sebagai lembaga penegak hukum menjadi tidak berdaya dan minim peran jika dibandingkan dengan lembaga ad boc terdahulu seperti IMTFE. Singkatnya, jika hukum humaniter ingin lebih ditegakkan, negara-negara perlu merancang aturan dan lembaga yang memiliki kuasa lebih luas.

\section{DAFTAR PUSTAKA \\ Buku}

Chang, I. (2009) The Rape of Nanking; The Forgotten Holocaust of World W ar II. Yogyakarta: Penerbit Narasi.

Effendi, M dan Ecandri, T. S. (2007) HAM dalam Dinamika: Dimensi Hukum, Politik, Ekonomi, dan Sosial. Bogor: Ghalia Indonesia.

Haryomataram, K.G.P.H. (2005) Pengantar Hukum Humaniter. Jakarta: Raja Grafindo Persada.

Nasution, A. B dan Zen, A. P. M. (2006) Instrumen Internasional Pokok Hak Asasi Manusia. Jakarta: Yayasan Obor Indonesia.

Sujatmoko, A. (2015) Hukum HAM dan Hukum Humaniter. Jakarta: Raja Grafindo Persada.

\section{Jurnal}

Casey, L. A. (2001) 'The Case Against the International Criminal Court', Fordham International Law Journal, Vol 25, Issue 3.

HZ, E. Deliana. (2011) 'Penegakan Hukum Humaniter Internasional Dalam Hal Terjadinya Kejahatan Perang Berdasarkan Konvensi Jenewa 1949', Jurnal Ilmu Hukum, Vol. 2 No.1.

Kattelman, K.T. (2012). 'Operation Enduring Freedom: Institutional Constraints, Alliance Commitments, and the Power Capabilities of Counterterrorism'. Journal of Terrorism Research, Vol 5. Issue 2. 


\section{Situs Web}

Bhaskara, Ign. L. A. (2018) Awal dari War on Terror': Serangan Amerika Serikat ke Afghanistan [online]. Available at: https://tirto.id/awal-dari-039war-onterror039-serangan-as-ke-afganistanc3Q6 (Diakses: 12 Februari 2019).

Bush, G.W (2002). The White House Washington [online]. Available at: https://georgewbushwhitehouse.archives.gov/nsc/nss/200 2/nssintro.html (Diakses: 6 Maret 2019).

Davert, D. (2018) Will the International Criminal Court Prosecute Americans Over Afghanistans? [online]. Available at: https://www.forbes.com/sites/david davenport/2018/03/26/will-theinternational-criminal-courtprosecute-americans-overafghanistan/\#433f68ff10a5 (Diakses: 14 Februari 2019).

Human Rights Watch. (2004) Enduring Freedom Abuses by U.S. Forces in Afghanistan [online]. Available at: https://www.hrw.org/report/2004/0 3/07/enduring-freedom/abuses-usforces-afghanistan (Diakses pada 18 Maret 2019).
Lambert, S. B. (2005) Operation Enduring Freedom An Assessment [online]. Available at: https://www.rand.org/pubs/research _briefs/RB9148/index1.html (Diakses: 6 Maret 2019).

Martowirono, H. S. (2001) 'Azas Pelengkap Statuta Roma 1998 tentang Pengadilan Pidana Internasional', [online]. Available at: jhp.ui.ac.id/index.php/ bome/article/downlo ad/1290/1212 (Diakses: 4 Maret 2019).

Widyaningrum, G. L. (2018) Kronologis Serangan 9/11, Runtubnya Menara Kembar, dan Osama Bin Laden [online]. Available at: https://nationalgeographic.grid.id/rea d/13935227/kronologis-serangan911-runtuhnya-menara-kembar-danosama-bin-laden?page $=$ all (Diakses: 14 Maret 2019). 